\title{
Laporan Kasus: COVID-19 dengan ARDS Berat dan Komorbiditas yang Bertahan tanpa Ventilasi Mekanik Invasif di ICU Rumah Sakit Darurat COVID-19 Wisma Atlet Kemayoran, Jakarta
}

\author{
Made Yudha Asrithari Dewi, Ahmad Irfan \\ Departemen Anestesiologi dan Terapi Intensif Rumah Sakit Darurat COVID-19 \\ Wisma Atlet Kemayoran Jakarta
}

\begin{abstract}
Abstrak
Sebagian besar orang yang terinfeksi COVID-19 asimtomatis ataupun bergejala ringan. Namun tidak sedikit juga yang mengalami acute respiratory distress syndrome (ARDS), membutuhkan perawatan ICU bahkan berakhir dengan kematian. Indonesia bahkan telah melampaui angka dunia dengan angka 2,7\%. Keadaan ini lebih berisiko dialami oleh pasien dengan komorbid seperti hipertensi $(50,1 \%)$, diabetes $(36,6 \%)$, dan obesitas $(13,3 \%)$. Kebutuhan terapi oksigen dengan ventilasi mekanik hingga tindakan intubasi meningkat pada kebanyakan kasus dengan komorbid. Serial kasus ini melaporkan dua pasien terkonfirmasi COVID-19 dengan komorbid yang memenuhi kriteria intubasi, namun tidak dilakukan. Dalam perjalanannya kedua kasus mengalami perbaikan klinis dan sembuh. Beberapa kemungkinan yang dapat dijelaskan, yaitu terdapat perbedaan antara ARDS pada COVID-19 (CARDS) dan ARDS klasik. Selain itu, prone position yang membantu meningkatkan oksigenasi dan mengatasi hipoksemia melalui beberapa mekanisme. Penggunaan HFNC dini pada pasien COVID-19 dan pemberian regimen kombinasi terapi antibiotik, antivirus, antikoagulan, serta antiinflamasi dinilai dapat menurunkan morbiditas pasien. Tujuan penanganan ARDS ialah menangani hipoksemia dengan meningkatkan oksigenasi. Selain dengan pemberian terapi oksigen untuk meningkatkan $\mathrm{FiO}_{2}$, dapat juga dilakukan dengan prone position. Prone position pada kasus dengan kombinasi HFNC dinilai berhasil karena pasien mampu bertahan tanpa penggunaan ventilasi mekanik dan mengalami perbaikan klinis hingga sembuh.
\end{abstract}

Kata kunci: ARDS, COVID-19, HFNC, ICU, prone position

\section{Two Reported Cases of COVID-19 with Severe ARDS and Comorbidities who Survived without Invasive Mechanical Ventilation in ICU at Wisma Atlet Kemayoran COVID-19 Field Hospital, Jakarta}

\begin{abstract}
Most patients with COVID-19 are either asymptomatic or have mild symptoms. However, many also experience acute respiratory distress syndrome (ARDS), requiring ICU, or even lead to death. Indonesia's case fatality rate of $2.7 \%$ has exceeded the global case. Patients with comorbidities such as hypertension $(50.1 \%)$, diabetes $(36.6 \%)$, and obesity $(13.3 \%)$ are at higher risk of experiencing this situation. The need for oxygen therapy with mechanical ventilation or even intubation is increased in most cases with previously mentioned comorbidities. These serial cases reported two confirmed COVID-19 patients with comorbidities that fulfilled intubation criteria; however, the intubation procedures were not performed. Both cases experienced clinical improvement and improved throughout the treatment period. Several possible explanations include that there are differences between ARDS in COVID-19 (CARDS) and classic ARDS. Moreover, the prone position helps in increasing oxygenation and reducing hypoxemia through several mechanisms. Early HFNC in COVID-19 patients and treatment regimen consisting of antibiotics, antivirus, anticoagulant, and anti-inflammatory drugs are considered to reduce morbidity. The goal of ARDS treatment is to treat hypoxemia by increasing oxygenation. In addition, giving oxygen therapy to increase $\mathrm{FiO}_{2}$ can also be done by prone positioning. Combining prone position and HFNC in these cases was considered successful because the patient were able to survive without the use of mechanical ventilation and experienced clinical improvement until they recovered.
\end{abstract}

Keywords: ARDS, COVID-19, HFNC, ICU, prone position

Korespondensi: dr. Made Yudha Asrithari Dewi, S. Ked, Departemen Anestesiologi dan Terapi Intensif Rumah Sakit Darurat COVID-19 Wisma Atlet Kemayoran Jakarta, Jl. Rd.H. Keneng Mudatsir No.13, RT.13/RW.6, Sunter Agung, Kec. Pademangan, Kota Jakarta Utara, Daerah Khusus Ibukota Jakarta 14360, Email asrithariawi@gmail.com 


\section{Pendahuluan}

Pandemi global oleh Corona virus disease 2019 (COVID-19) akibat infeksi severe acute respiratory syndrome corona virus 2 (SARSCOV2) telah satu tahun berlalu. ${ }^{1}$ Jumlah kasus COVID-19 di dunia hingga Mei 2021 telah mencapai 152 juta. $^{2}$ Sebagian besar (80\%) mengalami gejala ringan-sedang bahkan asimtomatis, $13,8 \%$ dengan gejala berat, dan $6,1 \%$ kritis. $^{3}$ Dalam perjalanannya, gejala berat akan jatuh dalam keadaan hipoksemia berat hingga kematian dalam 7-12 hari sejak onset gejala. ${ }^{4}$ Case fatality rate COVID-19 secara global mencapai $2,14 \%{ }^{5}$

Di China, angka kematian di intensive care unit (ICU) ditemukan sebanyak 49\% dari total 2.087 pasien gejala berat. ${ }^{6}$ Indonesia menempati angka kematian tertinggi di ASEAN sebesar 15,9\%. ${ }^{2}$ Berdasar atas studi meta-analisis sebanyak $32 \%$ pasien yang terinfeksi SARS-COV2 membutuhkan perawatan ICU.7 Jumlah kasus perawatan ICU di China sebanyak 6,1\% dengan kategori kritis (gagal napas, syok, gagal organ multipel) dan $13,8 \%$ kategori berat (sesak napas, $\mathrm{SpO}_{2} 93 \%$, P:F ratio $<300 \mathrm{mmHg}$ dan peningkatan infiltrat paru $>50 \%$ dalam 24-48 jam). ${ }^{6}$ Indonesia belum memiliki data lengkap kasus perawatan ICU COVID-19, namun berdasar atas data Kementerian Kesehatan bulan September 2020-Maret 2021 di Wisma Atlet Kemayoran Jakarta, akumulasi kasus kriteria berat dan memerlukan perawatan ICU mencapai 172 kasus. $^{8}$

Kriteria rawat ICU bergantung pada beratnya perjalanan penyakit, kebijakan rumah sakit setempat, dan sumber daya manusia serta peralatan. Hasil penelitian yang telah dilakukan menyatakan bahwa pasien yang berusia lebih tua dan memiliki komorbid lebih rentan mengalami gejala berat dan dirawat di ICU. ${ }^{6}$ Pada bulan Januari 2021 di Wisma Atlet Kemayoran Jakarta, komorbid yang terbanyak ditemukan yaitu hipertensi $(50,1 \%)$, diabetes $(36,6 \%)$, dan obesitas $(13,3 \%) .{ }^{8}$ Pada 7 hari pertama perawatan ICU, $12 \%$ pasien acute respiratory distress syndrome (ARDS) ringan dan 16\% ARDS sedang disertai komorbid, dapat memburuk menjadi ARDS berat. ${ }^{9}$ ARDS ditemukan pada $60-70 \%$ kasus di ICU dan kebanyakan (94\%) berakhir dengan kematian. ${ }^{10}$ Penelitian yang dilakukan di RSUD Soetomo Surabaya, dilaporkan 14 pasien dirawat di ICU, 100\% mengalami ARDS, 28,5\% menggunakan ventilator mekanik, 21,5\% bertahan, $7 \%$ weaning ventilator, serta $43 \%$ meninggal akibat acute kidney injury (AKI) dan syok sepsis. ${ }^{11}$.

Pada seri kasus ini, dilaporkan dua pasien dengan komorbid hipertensi dan obesitas yang memenuhi kriteria ARDS KigaliModified Berlin. Kedua pasien ini juga telah memenuhi kriteria intubasi dan pemasangan ventilator mekanik, namun tindakan tersebut ditunda dengan berbagai pertimbangan. Akan tetapi, kedua kasus tersebut mengalami perbaikan secara klinis sehingga pasien dapat dipulangkan hingga hasil swab RT-PCR dinyatakan negatif. Tujuan laporan kasus ini mengetahui lebih lanjut mengenai ARDS yang dipersulit dengan komorbiditas pada pasien COVID-19 serta penanganan hipoksemia melalui prone position yang dianggap berhasil menurunkan morbiditas dan mortalitas.

\section{Deskripsi Kasus \\ Kasus 1}

Pasien laki-laki 41 tahun dengan riwayat penyakit diabetes melitus, hipertensi dan obesitas (indeks massa tubuh [IMT] 34,6 kg/ $\mathrm{m}^{2}$ ) dirawat selama 7 hari dengan keluhan sesak dan batuk berdahak, dahak mudah dikeluarkan, kental berwarna putih. Riwayat konsumsi obat antihipertensi Irbesartan 1x150 mg, namun hanya dikonsumsi bila ada keluhan. Tanda vital awal di instalasi gawat darurat (IGD) tekanan darah 159/98 mmHg, laju nadi $121 \mathrm{x} /$ menit, laju napas $34 \mathrm{x} /$ menit, $\mathrm{SpO}_{2}$ 88\% dengan udara bebas, temperatur aksila $36,7^{\circ} \mathrm{C}$.Pada pemeriksaan, pasien tampak takipnea berat, tetapi masih dapat berbicara dalam kata. Pada auskultasi didapatkan suara ronki pada kedua lapang paru. Pemeriksaan fisis umum lainnya tidak ditemukan kelainan. Pemeriksaan laboratorium awal darah lengkap dan kimia darah normal (WBC 5,6×103/uL, neutrofil 70\%, limfosit 23\%). Gula darah 
sewaktu $227 \mathrm{mg} / \mathrm{dL}$. Pemeriksaan ronsen dada menunjukkan gambaran pneumonia bilateral tanpa kardiomegali. Hasil swab RT-PCR menunjukkan hasil positif. Kemudian pasien diberikan oksigen melalui non-rebreathing mask (NRM) 15 lpm untuk mempertahankan $\mathrm{SpO}_{2}>90 \%$ dengan $\mathrm{PaO}_{2}: \mathrm{FiO}_{2}$ (P:F) ratio 116 mmHg. Terapi Remdesivir dan Levofloxacin sudah dimulai di ruang Intermediate, namun kebutuhan oksigen semakin meningkat. Pasien segera dipindah ke ICU dengan highflow nasal cannula (HFNC) pada flow $50 \mathrm{lpm}$ $\mathrm{FiO}_{2}$ 65\%, P:F ratio $120 \mathrm{mmHg}$, dan tren ROX index 5,33-8,54. Hipoksemia terus memburuk hingga 4 hari berikutnya dengan kebutuhan $\mathrm{FiO}_{2}$ mencapai 90\%, ROX index terendah 3,31 poin, P:F ratio terendah $90 \mathrm{mmHg}$, dan hasil analisis gas darah menunjukkan alkalosis respiratorik. Tindakan intubasi dan ventilasi mekanik direncanakan jika ROX index $<3,88$ poin. Walaupun kebutuhan oksigen terus meningkat, work of breathing tampak minimal dan pasien dapat berkomunikasi/berbicara secara aktif.

Dalam kondisi hipoksemia berat, pasien disarankan posisi prone untuk meningkatkan oksigenasi, namun namun sulit dilakukan akibat ketidakmampuan mencapai posisi yang nyaman dan juga kondisi obesitas. Dengan bantuan tenaga medis, akhirnya pasien dapat menoleransi posisi prone, namun pasien mampu bertahan dalam prone selama 2-3 jam. Dalam beberapa jam posisi prone, $\mathrm{SpO}_{2}$ meningkat dari 93\% menjadi $98-99 \%$ dan $\mathrm{FiO}_{2}$ di titrasi turun hingga 75\%, P:F ratio 166 mmHg. Pasien terus melakukan posisi prone secara teratur selama $12 \mathrm{jam} /$ hari hingga $\mathrm{FiO}_{2}$ mampu disapih menjadi kanul nasal 5lpm pada hari ke-8. Beberapa hari kemudian, pasien tidak menggunakan bantuan oksigen lagi dan dapat bernapas dengan udara bebas sehingga pasien pulang dari perawatan dengan hasil swab RT-PCR negatif.

\section{Kasus 2}

Pasien laki-laki 47 tahun dengan riwayat penyakit hipertensi, dirawat di rumah sakit selama 9 hari dengan demam, pusing, dan lemas. Keluhan sesak disangkal. Tanda vital didapatkan tekanan darah 130/80 $\mathrm{mmHg}$, laju nadi 90x/menit, laju napas 33-34x/ menit, temperatur aksila $37,2^{\circ} \mathrm{C}, \mathrm{SpO}_{2} 89 \%$ dengan udara bebas, IMT $25,0 \mathrm{~kg} / \mathrm{m}^{2}$. Pada pemeriksaan auskultasi ditemukan ronki pada kedua hemitoraks. Pasien tampak sesak, namun masih dapat bicara dengan tersengalsengal. Pemeriksaan fisis lain dalam batas normal. Hasil laboratorium awal menunjukkan darah lengkap normal (WBC 8,6×103/uL, segmen neutrofil $86 \%$, limfosit 11\%), kimia darah didapatkan SGOT 91 U/L, SGPT 185 U/L. Foto toraks menunjukkan bronkopneumonia bilateral tanpa kardiomegali dan RT-PCR positif COVID-19. Pasien diberikan terapi oksigen non-rebreathing mask (NRM) $15 \mathrm{lpm}$ di IGD dengan P:F ratio $151 \mathrm{mmHg}$, namun laju napas dan saturasi tidak membaik sehingga pasien di transfer ke ICU untuk mendapatkan terapi antivirus, antibiotik, antikoagulan, dan anti-inflamasi melalui akses intravena, serta oksigenasi menggunakan HFNC dengan pengaturan flow $50 \mathrm{lpm} \mathrm{FiO}_{2} 70 \%$, P:F ratio $284 \mathrm{mmHg}$. Hipoksemia semakin memburuk dengan analisis gas darah menunjukkan alkalosis respiratorik hingga hari ke-13, pasien mengeluh batuk berdahak dan dahak sulit keluar. Kebutuhan oksigen semakin meningkat hingga $\mathrm{FiO}_{2}$ mencapai $90 \%$, ROX index terendah 3,61, P:F ratio $110 \mathrm{mmHg}$, hasil ronsen toraks evaluasi menunjukkan peningkatan inflitrat pada kedua hemitoraks. Pasien selama perawatan dimotivasi untuk selalu melakukan posisi prone, tindakan intubasi dipersiapkan jika keadaan semakin memburuk. Walaupun dirasa tidak nyaman, posisi prone dapat dilakukan maksimal 9 jam/ hari. Nilai $\mathrm{SpO}_{2}$ meningkat dari 93\% menjadi $100 \%$ dan $\mathrm{FiO}_{2}$ diturunkan menjadi $60 \%$, P:F ratio $163 \mathrm{mmHg}$. Selama 3 hari setelahnya, pasien masih batuk berdahak dan setiap kali batuk selalu terjadi desaturasi dengan $\mathrm{SpO}_{2}$ maksimal 93\% saat supine, $97 \%$ saat posisi prone, dengan tren ROX index 6,15-8,96 poin, P:F ratio terendah $63,5 \mathrm{mmHg}$. Hari ke-5 proning pasien berhasil disapih hingga menggunakan kanul nasal $3 \mathrm{lpm}$. Evaluasi hasil ronsen menunjukkan perbaikan. Pasien dipulangkan setelah tidak menggunakan 
bantuan terapi oksigen dan swab RT-PCR negatif pada hari perawatan ke-20.

\section{Diskusi}

Pada kasus pertama, perburukan klinis terjadi pada hari ke-10 sampai hari ke-16 dari onset dengan keluhan sesak memberat, laju napas di atas 30x/menit, $\mathrm{SpO}_{2}$ terukur paling rendah 88\% dengan $\mathrm{HFNC} \mathrm{FiO}_{2}$ 65\% flow $50 \mathrm{lpm}$, ROX index 3,31 poin dan P:F ratio terendah 90 mmHg. Ronsen dada menunjukkan peningkatan infiltrat (Gambar 1) dan terjadi alkalosis respiratorik. Pada kasus kedua perburukan terjadi antara hari ke-11 sampai ke-17 dari onset gejala, laju napas paling tinggi terhitung 30x/menit, $\mathrm{SpO}_{2}$ terendah $78 \%$ menggunakan HFNC flow $50 \mathrm{lpm} \mathrm{FiO}_{2} 90 \%$, ROX index 3,61 poin, P:F ratio terendah 63,5. Sama halnya seperti kasus 1, ditemukan pula alkalosis respiratorik dan hasil pemeriksaan ronsen dada serial menunjukkan peningkatan infiltrat yang signifikan (Gambar 2).

Berdasar atas Kigali modification of the Berlin criteria tahun 2017 kedua kasus termasuk kriteria ARDS, derajat berat (P:F ratio $\leq 100$ ) yang membutuhkan ventilasi mekanik invasif. ${ }^{12}$ ARDS diawali dengan sesak napas (dispnea dan takipnea) yang secara progresif dapat berubah menjadi gagal napas. ${ }^{13}$ Secara umum, hipoksemia pada penyakit paru menyebabkan hiperventilasi yang mengakibatkan $\mathrm{CO}_{2}$ keluar dalam jumlah besar. $^{14}$ Meskipun beberapa pasien tidak menunjukkan hipoksemia yang signifikan pada tahap awal, jika terjadi alkalosis respiratorik maka pasien masukdalam periode kompensasi hiperventilasi yang akan segera memburuk..$^{15}$ Kebanyakan kasus COVID-19 mengalami periode kompensasi hiperventilasi dan alkalosis respiratorik sebelum terjadi dekompensasi yang kemudian menjadi gagal napas. ${ }^{16}$ Pasien dengan alkalosis respiratorik $(28,7 \%)$ secara signifikan meningkatkan risiko COVID-19 gejala berat bahkan kematian. ${ }^{15}$ ARDS pada COVID-19 dapat terjadi akibat cytokine storm atau cytokine release syndrome (CRS). Aktivasi berbagai sistem imun; seperti makrofag, antigen-presenting cell, sel $\mathrm{T}$ dan sel B; menyebabkan pelepasan faktor-faktor proinflamasi dalam jumlah besar; termasuk sitokin, kemokin, dan interleukin khususnya interleukin-6. Hal tersebut menyebabkan peningkatan permeabilitas vaskular sehingga sejumlah besar kantong cairan kolaps dan sel darah masuk ke alveloli yang berakibat sesak bahkan gagal napas. ${ }^{17}$ Jika dilihat dari perjalanan penyakit COVID-19 yang terdiri atas 3 fase; CRS terjadi pada fase ketiga atau fase hiperinflamasi sistemik yang ditandai dengan ARDS, syok, hingga henti jantung.

Fase hiperinflamasi ini diduga terjadi antara hari ke-3 perawatan sampai 16 hari setelah onset gejala. ${ }^{10}$ Pada kedua kasus terjadi perburukan kondisi pada hari ke-10 sampai hari ke-17 dari onset gejala yang menunjukkan CRS saat itu sedang berlangsung, dan menyebabkan ARDS berat. Kedua kasus memenuhi kriteria intubasi, namun tidak dilakukan dengan berbagai pertimbangan, yaitu perbaikan hasil analisis gas darah setelah pemberian HFNC, peningkatan poin ROX index setelah evaluasi 2 jam pertama HFNC, dan klinis berangsur membaik dengan prone position. Kenyataannya, keduanya mengalami perbaikan klinis dan bertahan tanpa intubasi dan ventilasi mekanik.

Terdapat asumsi bahwa ARDS pada COVID-19 (CARDS) berbeda dengan ARDS klasik. CARDS memiliki 2 fenotipe berbeda yaitu tipe L dan H. Tipe L memiliki karakteristik peningkatan infiltrat hanya di beberapa area terbatas yang terlihat pada gambaran CTscan thorax sebagai ground glass appearance. Kebanyakan pasien tidak mengeluhkan sesak napas, namun kondisi oksigenasi buruk, hipoksemia dengan klirens $\mathrm{CO}_{2}$ yang baik (gagal napas tipe 1), dan elastance yang rendah (compliance tinggi). CARDS tipe L juga dapat bertahan tanpa penggunaan ventilasi mekanik. Pemberian terapi oksigen dilakukan untuk memulihkan keadaan hipoksemia dengan cara meningkatkan $\mathrm{FiO}_{2}$. Pilihan terapi noninvasif seperti HFNC, continuous positive airway pressure (CPAP) atau non-invasive ventilation (NIV). Tipe $\mathrm{H}$ diduga memiliki karakteristik lebih berat dari tipe L. Pada tipe $\mathrm{H}$ ditemukan konsolidasi luas pada CT-scan 


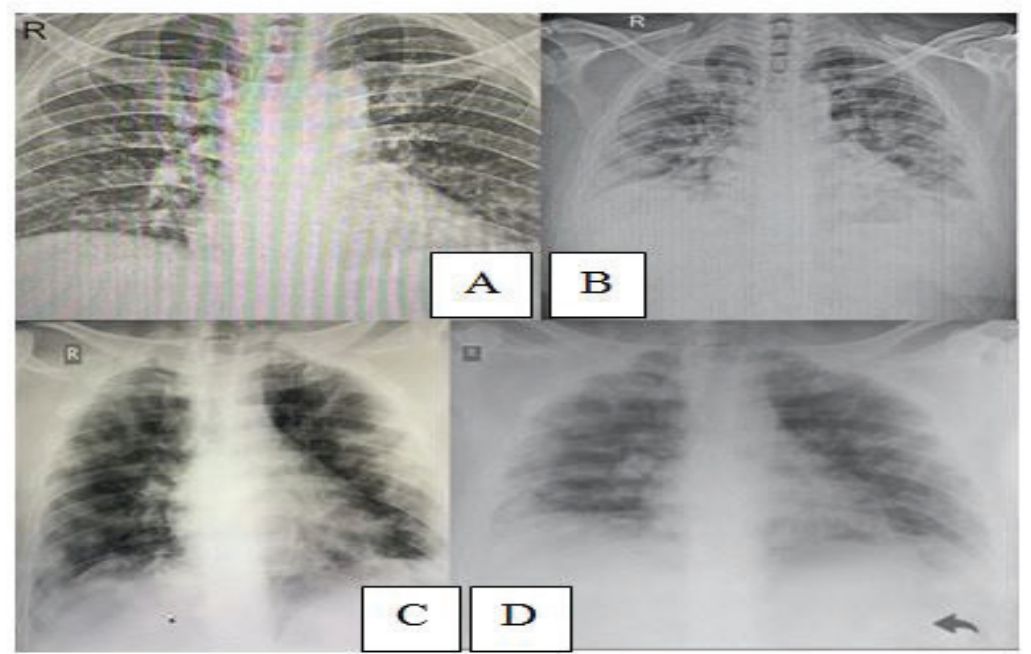

\section{Gambar 1 Ronsen Toraks Serial Kasus 1}

Ket: A) Hari pertama masuk rumah sakit, kesan tidak tampak kelainan B) Hari ke-7, kesan pneumonia bilateral C) Hari ke-10, pasien perburukan, kesan bronkopneumonia bilateral D) Hari ke-18, bronkopneumia membaik

Sumber: dokumentasi pribadi

toraks dan lebih disarankan menggunakan ventilasi mekanik. Perbedaan tipe $L$ dengan $H$ hanya dapat dilihat dari hasil CT-scan toraks, tipe $\mathrm{H}$ terlihat gambaran tipikal ARDS. ${ }^{10}$ Kedua kasus memenuhi karakteristik CARDS tipe L paru pada kedua kasus masih memiliki compliance yang tinggi. Tipe $\mathrm{L}$ dapat bertahan bahkan membaik tanpa penggunaan ventilasi mekanik. Pada kedua kasus, modalitas oksigenasi menggunakan HFNC sebagai upaya memperbaiki keadaan hipoksemia. Namun, asumsi ini belum dapat dikonfirmasi karena pada saat pasien mengalami perburukan, pemeriksaan CT-scan toraks tidak dapat dilakukan karena belum tersedia di rumah sakit kami.

Komorbid pada COVID-19 yang paling banyak ditemukan antara lain hipertensi, obesitas dan diabetes. ${ }^{18}$ Obesitas diduga menjadisalahsatupenyebabterseringkematian COVID-19. ${ }^{19}$ Jaringan adiposa menginduksi inflamasi kronik derajat rendah, ditandai oleh

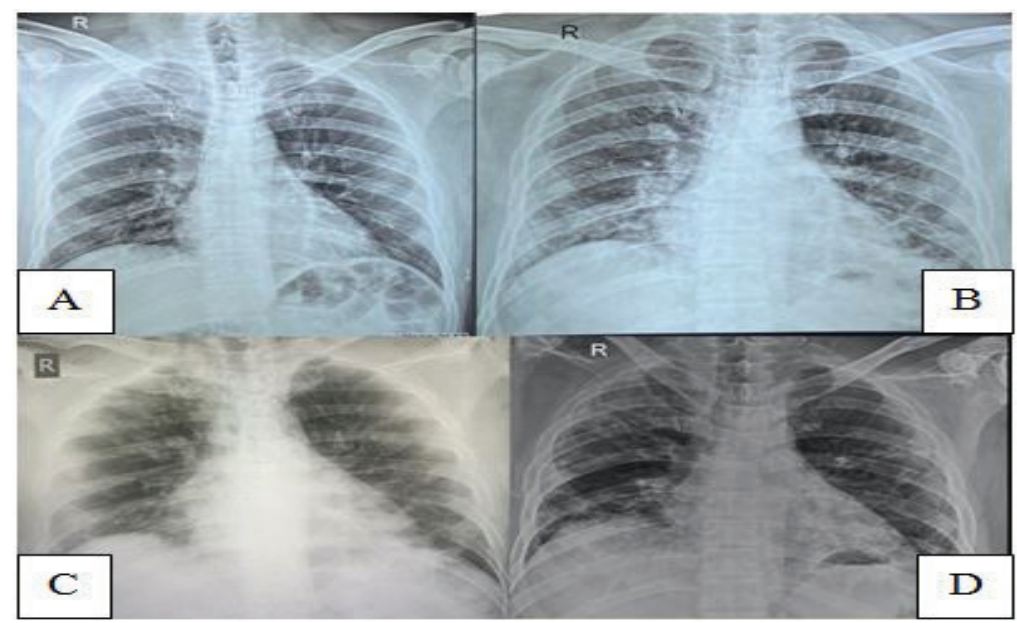

Gambar 2 Ronsen Toraks Serial Kasus 2

Ket: A) Hari pertama masuk rumah sakit, kesan tidak bronkopneumonia bilateral B) Hari ke-7 C) Hari ke-16, pasien perburukan, kesan bronkopneumonia bilateral D) Hari ke-19, bronkopneumia membaik 
peningkatan kadar sitokin proinflamasi dan penurunan sitokin anti-inflamasi (adiponectin dan IL-10). Hal ini menyebabkan kelelahan sel $\mathrm{T}$ yang mengganggu respons dan kemampuan mengeradikasi virus dari host. Aspek krusial lain pada obesitas ialah kurangnya aktivitas yang juga dapat menggangu aktivasi sel imun. SARS-COV2 berikatan dengan reseptor ACE2 banyak terdapat pada alveolus dan juga di jaringan adiposa. Virus tersebut menyebabkan peningkatan apoptosis limfosit dan mengganggu fungsi limfosit yang mengakibatkan badai sitokin fulminan yang ditandai dengan kadar IL-6, IL-2, IL-7, dan TNFa berlebih disirkulasi. Sebagai tambahan, volume jaringan adiposa yang besar pada obesitas, sedangkan jumlah reseptor ACE2 berbanding lurus dengan volume jaringan adiposa sehingga cenderung menjadi host dan berperan sebagai wadah sejumlah besar virus yang mengakibatkan peningkatan viral shedding, inaktivasi virus, dan cytokine storm. Efek obesitas pada COVID-19 ini berhubungan dengan komorbid lain seperti diabetes, hipertensi, dan penyakit kardiovaskular. $^{19}$ Pada kasus 1, pasien memiliki IMT 34,6 kg/ $\mathrm{m}^{2}$ termasuk dalam obesitas grade II dan memiliki riwayat hipertensi serta diabetes. Pada kasus 2 didapatkan komorbid hipertensi stage 1. Komorbid tersebut meningkatkan risiko morbiditas dan mortalitas pasien.

ARDS pada COVID-19 dapat memburuk jika tidak segera ditangani. Tujuan utama penanganan meningkatkan oksigenasi dengan pemberian terapi oksigen dan prone position (20). Memposisikan pasien dalam prone menyebabkan konfigurasi dan perfusi alveolus yang lebih teratur sehingga mengurangi ketidaksesuaian ventilasi/perfusi (V/Q missmatch), hipoksemia, dan shunting. ${ }^{20,21}$ Melalui beberapa mekanisme: transpulmonary pressure (TPP) gradien, mengurangi kompresi paru, dan shape matching. Prone position mengurangi gradien tekanan pleura antara regio paru dependen dan non-dependen dari efek gravitasi dan kesesuaian bentuk konformasi paru dengan rongga dada. Hal ini dapat menyebabkan aerasi paru dan distribusi tekanan yang lebih homogen sehingga meningkatkan recruitment unit paru dorsal. Pemakaian positive end-expiratory pressure (PEEP) melalui HFNC, NIV, atau CPAP dalam menangani ARDS bermanfaat mencegah de-recruitment alveolar, tetapi juga dapat menyebabkan overdistensi alveoli yang sebelumnya well-ventilated. Kombinasi prone position dengan penggunaan HFNC atau NIV/ CPAP dapat membantu mengurangi sebagian efek merugikan ini dengan mengurangi hiperinflasi regional. Prone position juga dapat meningkatkan klirens sekresi. Orientasi dorsal ke ventral dari jalan napas utama mengakibatkan drainase sekresi lebih efisien. ${ }^{20,22}$

Penilaian keberhasilan prone position terhadap oksigenasi dapatdinilai dari beberapa indikator, yaitu peningkatan $\mathrm{SpO}_{2}$, perbaikan hasil analisis gas darah terutama tekanan oksigen parsial dan saturasi oksigen darah arteri yang secara signifikan terjadi pada 3 hari pertama. ${ }^{23}$ Pada studi di Spanyol didapatkan sebanyak $80 \%$ pasien ARDS mengalami peningkatan $\mathrm{PaO}_{2}$ setelah melakukan 30 menit prone position, ${ }^{24}$ sedangkan sebuah studi meta-analisis pada 1.372 pasien menunjukkan peningkatan signifikan P:F ratio. ${ }^{25} \mathrm{PubMed}$, CINAHL, and Embase (to November 2007 Evaluasi keberhasilan kombinasi HFNC dan prone position juga harus dinilai setiap 1-2 jam menggunakan indeks ROX. Penggunaan HFNC dianggap berhasil dan tidak membutuhkan ventilasi invasif jika indeks ROX ${ }^{3} 4,88$ yang dinilai pada jam ke-2, 6, dan 12. Sebaliknya, jika $<3,85$ diperkirakan kebutuhan intubasi semakin meningkat. ${ }^{26}$ Pada kedua kasus, pasien berhasil mempertahankan posisi prone maksimal selama 9 jam/hari selama 5-8 hari. Dalam observasi selama prone position terjadi penurunan kebutuhan oksigen, $\mathrm{FiO}_{2}$ dapat dititrasi turun $15-30 \%$, terjadi peningkatan indeks ROX dan P:F ratio 50-70 mmHg sehingga belum perlu untuk dilakukan intubasi.

Dari kedua kasus di atas dapat diambil pelajaran bahwa tidak semua pasien COVID-19 dengan ARDS berat disertai komorbitas harus dilakukan tindakan intubasi. Ancaman intubasi dapat dicegah melalui upaya prone position 
yang dapat meningkatkan oksigenasi melalui berbagai mekanisme untuk mengurangi risiko terjadi hipoksemia. Penggunaan HFNC dini juga dianggap berhasil dalam mengatasi hipoksemia dan memperbaiki klinis pasien secara signifikan. Ke depannya diharapkan agar modalitas terapi oksigen dengan HFNC yang dapat dikombinasi dengan prone position dapat diterapkan tidak hanya pada pasien COVID-19, namun pada pasien dengan ARDS ringan hingga berat. Pilihan kombinasi terapi ini diharapkan dapat mencapai $\mathrm{SpO}_{2}$ yang optimal, perbaikan hasil analisis gas darah terutama tekanan oksigen parsial dan saturasi oksigen darah arteri.

\section{Simpulan}

Pemahaman perjalanan penyakit sangat penting untuk menentukan penatalaksanaan yang tepat dan adekuat. Mekanisme yang mendasari fenomena CARDS, yaitu CRS yang terjadi antara hari ke-3 hingga ke-16 dari onset gejala. CARDS tipe L dapat bertahan walaupun tanpa tindakan intubasi dan penggunaan ventilasi mekanik, meskipun telah memenuhi kriteria ARDS Kigali modification of the Berlin. Obesitas menjadi komorbid yang paling sering menyebabkan kematian pada ARDS yang juga berhubungan dengan komorbid lain seperti hipertensi, diabetes, dan penyakit kardiovaskular. Tujuan penanganan ARDSialah menangani hipoksemia dengan meningkatkan oksigenasi. Selain dengan pemberian terapi oksigen untuk meningkatkan $\mathrm{FiO}_{2}$, dapat juga dilakukan dengan prone position. Prone position pada kasus dengan kombinasi HFNC dinilai berhasil karena pasien mampu bertahan tanpa penggunaan ventilasi mekanik dan mengalami perbaikan klinis hingga sembuh.

\section{Daftar Pustaka}

1. Huang $Y$, Lu Y, Huang Y-M, Wang $M$, Ling W, Sui Y, dkk. Obesity in patients with COVID-19: a systematic review and metaanalysis. Metab Clin Exp. 2020;113:1-11.

2. WHO. WHO Coronavirus (COVID-19) dashboard: overview [Internet]. 2021 [diunduh 4 Mei 2021]. Tersedia dari: https://covid19.who.int.

3. Susilo A, Rumende CM, Pitoyo CW, Santoso WD, Yulianti M, Herikurniawan H, dkk. Coronavirus disease 2019: tinjauan literatur terkini. J Penyakit Dalam Indones. 2020;7(1):45.

4. Cao J, Hu X, Cheng W, Yu L, Tu WJ, Liu Q. Clinical features and short-term outcomes of 18 patients with corona virus disease 2019 in intensive care unit. Intens Care Med. 2020;46(5):851-3.

5. Lippi G, Henry BM, Mattiuzzi C, Bovo C. COVID-19 virus case fatality rate: how to avoid errors in calculation of data during the outbreak? Acta Biomed. 2020; 91(2):224-5.

6. Phua J, Weng L, Ling L, Egi M, Lim CM, Divatia JV, dkk. Intensive care management of coronavirus disease 2019 (COVID-19): challenges and recommendations. Lancet Respir Med. 2020;8(5):506-17.

7. Abate SM, Ali SA, Mantfardo B, Basu B. Rate of intensive care unit admission and outcomes among patients with coronavirus: a systematic review and Meta-analysis. PLoS One. 2020 Juli;15:119.

8. Kemenkes RI. Sistem Informasi Rumah Sakit Darurat COVID-19 [Internet]. 2021 [diunduh 22 April 2021]. Tersedia dari: http://simrsdc.kemkes.go.id/.

9. Schmidt M, Hajage D, Demoule A, Pham $\mathrm{T}$, Combes A, Dres M, dkk. Clinical characteristics and day-90 outcomes of 4244 critically ill adults with COVID-19: a prospective cohort study. Intens Care Med. 2021;47(1):60-73.

10. Soeroto AY, Hartantri Y, Perkusi JE, Ferdian F, Rehimat U, Suryadinata H. Report of two COVID-19 ARDS (CARDS) cases who survived without intubation and mechanical ventilation. Acta Med Indones. 2020;52(3):274-82.

11. Soedarsono S, Semedi BP, Setiawati R, Meliana RY, Kusmiati T, Permatasari A, dkk. Case report: survival of a coronavirus disease-2019 (Covid-19) patient with acute respiratory distress syndrome (ARDS) in 
Dr. Soetomo Hospital, Surabaya, Indonesia. Folia Medica Indones. 2021;56(3):235.

12. Confalonieri M, Salton F, Fabiano F. Acute respiratory distress syndrome. Eur Respir Rev. 2017;26(144):160116.

13. Bakhtiar A, Maranatha RA. Acute respiratory distress syndrome. J Respirasi. 2018;4(2):51-60.

14. Brinkman JE, Sharma S. Respiratory alkalosis [Internet]. StatPearls. 2021 [diunduh 3 Juni 2021]. Tersedia dari: https://www.ncbi.nlm.nih.gov/books/ NBK482117/.

15. Wu C, Wang G, Zhang Q, Yu B, Lv J, Zhang $S$, dkk. Association between respiratory alkalosis and the prognosis of COVID-19 patients. Front Med. 2021;8:6-11.

16. Seers T, Davenport R. Phosphate metabolism and respiratory alkalosis: a forgotten lesson in COVID-19. Age Ageing. 2020;49(6):927.

17. Zhang C, Wu Z, Li J, Zhao H, Wang G. Cytokine release syndrome in severe COVID-19: interleukin-6 receptor antagonist. Int J Antimicrob Agents. 2020;55(2020):105954-60.

18. Karyono DR, Wicaksana AL. Current prevalence, characteristics, and comorbidities of patients with COVID-19 in Indonesia. J Community Empower Heal. 2020;3(2):77.

19. Chiumello D, Pozzi T, Storti E, Caccioppola A, Pontiroli AE, Coppola S. Body mass index and acute respiratory distress severity in patients with and without SARS-CoV-2 infection. Br J Anaesth. 2020;125(4):3767.
20. Paul V, Patel S, Royse M, Odish M, Malhotra A, Koenig S. Proning in non-intubated (PINI) in times of COVID-19: case series and a review. J Intens Care Med. 2020;35(8):818-24.

21. Sztajnbok J, Maselli-Schoueri JH, Cunha de Resende Brasil LM, Farias de Sousa L, Cordeiro CM, Sansão Borges LM, dkk. Prone positioning to improve oxygenation and relieve respiratory symptoms in awake, spontaneously breathing non-intubated patients with COVID-19 pneumonia. Respir Med Case Reports. 2020;30:101096.

22. Koeckerling D, Barker J, Mudalige NL, Oyefeso 0, Pan D, Pareek M, dkk. Awake prone positioning in COVID-19. Thorax. 2020;75(10):833-4.

23. Marini JJ, Gattinoni L. Management of COVID-19 respiratory distress. JAMA. 2020;323(22):2329-30.

24. Jahani S, Hajivand Soleymani Z, Asadizaker M, Soltani F, Cheraghian B. Determination of the effects of prone position on oxygenation in patients with acute respiratory failure under mechanical ventilation in ICU. J Med Life. 2018;11(4):274-80.

25. Abroug F, Ouanes-Besbes L, Elatrous S, Brochard L. The effect of prone positioning in acute respiratory distress syndrome or acute lung injury: a meta-analysis. Areas of uncertainty and recommendations for research. Intens Care Med. 2008;34 (6):1002-11.

26. Kemenkes RI. Protokol tata laksana COVID-19 Buku Saku. Jakarta: Kementrian Kesehatan Republik Indonesia. 2020. 